\title{
Predictors of weaning from helmet CPAP in patients with COVID-19 pneumonia
}

\author{
Dejan Radovanovic, Stefano Pini, Marina Saad, Luca Perotto, Fabio Giuliani and Pierachille Santus* (1)
}

Continuous positive airway pressure (CPAP) offers a valid non-invasive respiratory support for patients with Coronavirus Disease 2019 (COVID-19) pneumonia [1]. CPAP treatment isn't free from complications such as pneumothorax/pneumomediastinum, hemodynamic instability, or delirium and requires careful monitoring $[1,2]$. Accordingly, timely CPAP removal appears desirable $[1,2]$. Our aim was to identify weaning predictors and assess their performance in COVID-19 patients treated with helmet CPAP.

A prospective, observational, cohort study was conducted in our high dependency respiratory unit including consecutive adult patients with laboratory confirmed COVID-19 pneumonia that underwent a weaning trial from CPAP between March 2020 and February 2021 (training cohort).

Patients' readiness to undergo a weaning trial was judged by the treating physician. A weaning trial was the reduction in support to minimal positive end-expiratory pressure ( $\mathrm{PEEP} \approx 2 \mathrm{cmH}_{2} \mathrm{O}$, including antiviral filters) maintaining a $\mathrm{FiO}_{2} \leq 60 \%[1,2]$. Absence of respiratory distress and $\mathrm{SpO}_{2} \geq 94 \%$ in the subsequent $30 \mathrm{~min}$ lead to helmet removal and oxygen supplementation with $\mathrm{FiO}_{2} \leq 60 \%$. A weaning failure was the need to restore CPAP because of respiratory distress or $\mathrm{SpO} 2 \leq 94 \%$ in any moment beginning from the low PEEP trial and during the subsequent $12 \mathrm{~h}$.

Weaning predictors were assessed before reducing PEEP, and included: (1) ROX index $\left(\mathrm{SpO}_{2} / \mathrm{FiO}_{2} /\right.$

\footnotetext{
${ }^{*}$ Correspondence: pierachille.santus@unimi.it

Division of Respiratory Diseases, Ospedale Luigi Sacco, Polo Universitario,

ASST Fatebenefratelli-Sacco, Department of Biomedical and Clinical

Sciences (DIBIC), Università Degli Studi Di Milano, Via G.B. Grassi 74

20157 Milan, Italy
}

respiratory rate (RR)) [3], (2) modified ROX index (partial pressure of oxygen $\left(\mathrm{PaO}_{2}\right)$ to $\mathrm{FiO}_{2}$ ratio/RR-mROX) [3], (3) alveolar-arterial (A-a) $\mathrm{O}_{2}$ gradient, (4) Sequential Organ Failure Assessment (SOFA) score [4].

Sensitivity and specificity for different thresholds and the area under the receiver operating characteristic curve (AUROC) was calculated for all indexes. The index that best performed in the training cohort was tested in a validation cohort of patients hospitalized in two general wards of our institution. Statistical significance was a $p$ value $\leq 0.05$. Analyses were performed with IBM SPSS Statistics V.23.0 (Armonk, NY). The study (NCT04307459) was approved by the local ethical committee (17263/2020) and all patients gave written informed consent.

Seventy-four patients formed the training cohort: 61 (82.5\%) succeeded and 13 (17.5\%) failed the weaning trial (Table 1). At weaning trial, patients that failed had higher SOFA score, A-a $\mathrm{O}_{2}$ and $\mathrm{RR}$, while $\mathrm{PaO}_{2} / \mathrm{FiO}_{2}$, $\mathrm{ROX}$ and mROX were higher in patients that succeeded weaning (Table 1). The mROX index had the best AUROC (0.830) and the value that best discriminated weaning success from failure was $8.4 \mathrm{mmHg} / \mathrm{bpm}$ (sensitivity 0.80 , specificity 0.77 ) (Fig. 1). This threshold was tested in the validation cohort (44 patients; median age $65,82 \%$ males) of which $32(72.7 \%)$ succeeded and 12 (27.3\%) failed weaning. The two cohorts were comparable in terms of clinical characteristics and CPAP duration before weaning. AUROC for mROX in the validation cohort was 0.828 , sensitivity and positive predictive value 0.88 , specificity and negative predictive value 0.67 . Patients with mROX $\geq 8.4$ after 5 days of CPAP had twice the probability to be free from CPAP compared with patients with mROX $<8.4$ (Fig. 1). original author(s) and the source, provide a link to the Creative Commons licence, and indicate if changes were made. The images or other third party material in this article are included in the article's Creative Commons licence, unless indicated otherwise in a credit line to the material. If material is not included in the article's Creative Commons licence and your intended use is not permitted by statutory regulation or exceeds the permitted use, you will need to obtain permission directly from the copyright holder. To view a copy of this licence, visit http://creativecommons.org/licenses/by/4.0/. The Creative Commons Public Domain Dedication waiver (http://creativeco mmons.org/publicdomain/zero/1.0/) applies to the data made available in this article, unless otherwise stated in a credit line to the data. 
Table 1 Clinical characteristics at admission and at weaning trial in patients that succeeded and failed CPAP weaning

\begin{tabular}{|c|c|c|c|}
\hline Characteristics & Weaning success $(n=61)$ & Weaning failure $(n=13)$ & $p$ value $^{a}$ \\
\hline Age, years & $62(12)$ & $74(8)$ & 0.001 \\
\hline Males, n (\%) & $43(70)$ & $8(61)$ & 0.526 \\
\hline Hypertension, n (\%) & $30(49)$ & $7(54)$ & 0.760 \\
\hline Diabetes mellitus, n (\%) & $13(21)$ & $3(23)$ & 0.999 \\
\hline Ischemic heart disease, n (\%) & $6(10)$ & $4(31)$ & 0.067 \\
\hline Obesity, n (\%) & $26(43)$ & $6(46)$ & 0.816 \\
\hline Respiratory disease, n (\%) & $10(16)$ & $0(0)$ & 0.116 \\
\hline CPAP days at weaning trial & $4(2-6)$ & $4(2.5-5)$ & 0.854 \\
\hline \multicolumn{4}{|l|}{ In-Hospital treatments } \\
\hline Antibiotics, n (\%) & $50(82.0 \%)$ & $9(69.2 \%)$ & 0.446 \\
\hline LMWH prophylactic, n (\%) & $39(63.9 \%)$ & $8(61.5 \%)$ & 0.999 \\
\hline LMWH therapeutic, n (\%) & $30(49.2 \%)$ & $9(69.2 \%)$ & 0.189 \\
\hline Systemic corticosteroids, n (\%) & $46(75.4 \%)$ & $9(69.2 \%)$ & 0.729 \\
\hline \multicolumn{4}{|l|}{ Clinical status at admission } \\
\hline Lymphocytes, $\times 10^{6} / \mathrm{L}$ & $900(600-1400)$ & $800(700-1000)$ & 0.931 \\
\hline D-Dimer, $\mu \mathrm{g} / \mathrm{L}$ FEU & $888(572-2101)$ & $1056(544-1632)$ & 0.922 \\
\hline $\mathrm{CRP}, \mathrm{mg} / \mathrm{L}$ & $85(42-127)$ & $110(85-215)$ & 0.060 \\
\hline Creatinine, mg/dL & $0.8(0.7-1.0)$ & $0.9(0.8-1.6)$ & 0.091 \\
\hline BUN, mg/dL & $38(28-53)$ & $52(34-70)$ & 0.093 \\
\hline Glasgow coma scale & $15(15-15)$ & $15(14.5-15)$ & 0.067 \\
\hline SOFA & $2(2-3)$ & $3(2-4.5)$ & 0.204 \\
\hline Respiratory rate, bpm & $24(22-29)$ & $26(24-33)$ & 0.275 \\
\hline $\mathrm{PaO}_{2} / \mathrm{FiO}_{2}, \mathrm{mmHg}$ & $194(122-273)$ & $140(86.7-281.0)$ & 0.604 \\
\hline A- $\mathrm{a} \mathrm{O}_{2}$ gradient, $\mathrm{mmHg}$ & $204(69-325)$ & $242(66-336)$ & 0.960 \\
\hline $\mathrm{pH}$ & $7.48(0.05)$ & $7.49(0.05)$ & 0.389 \\
\hline $\mathrm{PaCO}_{2}, \mathrm{mmHg}$ & $36(7)$ & $35(9)$ & 0.598 \\
\hline ROX index & $7.6(4.8-14.5)$ & $8.1(4.3-16.3)$ & 0.889 \\
\hline \multicolumn{4}{|c|}{ Clinical status the day of weaning trial } \\
\hline D-Dimer, $\mu \mathrm{g} / \mathrm{L}$ FEU & $899(545-1425)$ & $1244(845-1375)$ & 0.183 \\
\hline $\mathrm{CRP}, \mathrm{mg} / \mathrm{L}$ & $36(9-59)$ & $70(18-115)$ & 0.085 \\
\hline SOFA & $2(1.5-3)$ & $3(3-4)$ & 0.003 \\
\hline GCS & $15(15-15)$ & $15(15-15)$ & 0.423 \\
\hline A-a $\mathrm{O}_{2}$ gradient, $\mathrm{mmHg}$ & $208(151-269)$ & $245(206-445)$ & 0.010 \\
\hline $\mathrm{PaO}_{2} / \mathrm{FiO}_{2}, \mathrm{mmHg}$ & $243(98)$ & $171(56)$ & 0.014 \\
\hline Respiratory rate, bpm & $20(18-22)$ & $24(22-27)$ & $<0.001$ \\
\hline $\mathrm{pH}$ & $7.45(7.42-7.47)$ & $7.44(7.42-7.48)$ & 0.638 \\
\hline $\mathrm{PaCO}_{2}, \mathrm{mmHg}$ & $42(6)$ & $41(6)$ & 0.653 \\
\hline ROX index & $9(8-11)$ & $7.4(4.1-8.5)$ & 0.002 \\
\hline mROX index, mmHg/bpm & $11.9(8.5-14.3)$ & $6.6(5.6-8.8)$ & $<0.001$ \\
\hline
\end{tabular}

Parametric and nonparametric quantitative variables are described with means (standard deviations, SD) and medians (interquartile ranges, IQR), respectively. Chisquared or Fisher exact test were used to compare qualitative variables, whereas Student $t$ test or Mann-Whitney were used to compare quantitative variables with normal or non-normal distribution, respectively, in patients that failed or succeeded the weaning trial

$\mathrm{A}-\mathrm{a} \mathrm{O}_{2}$ gradient $=$ alveolar-arterial oxygen gradient; $\mathrm{BUN}=$ blood urea nitrogen; $\mathrm{CPAP}=$ continuous positive airway pressure; $\mathrm{CRP}=\mathrm{C}$ reactive protein (upper limit of

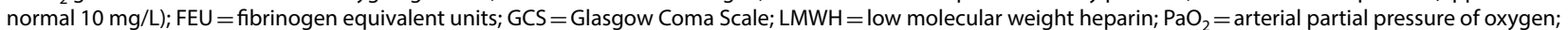
$\mathrm{PaCO}_{2}=$ arterial partial pressure of carbon dioxide; $\mathrm{ROX}$ index $=\mathrm{SpO}_{2} / \mathrm{FiO}_{2} /$ respiratory rate; $\mathrm{mROX}$ index $=\mathrm{PaO}_{2} / \mathrm{FiO} \mathrm{O}_{2} /$ respiratory rate; SOFA $=\mathrm{Sequential}$ Organ Failure Assessment

Our data demonstrated that the mROX index, combining non-invasive surrogates of respiratory distress (RR) and gas exchange efficiency $\left(\mathrm{PaO}_{2} / \mathrm{FiO}_{2}\right)$, was the best predictor of weaning success from CPAP. We observed a relatively low rate of weaning failure, suggesting that weaning attempts tend to be performed 


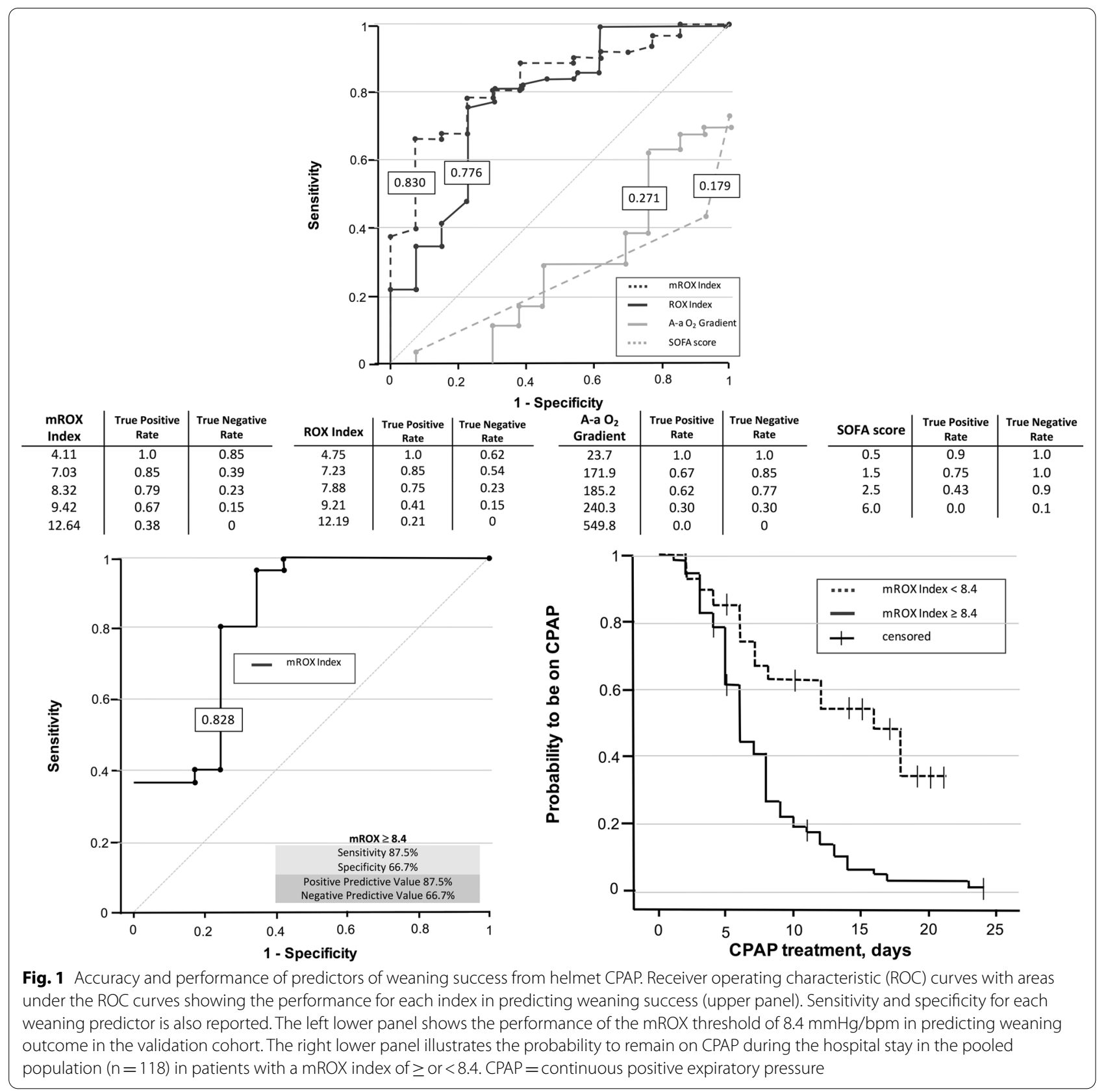

late, and reflecting the need for objective and sensitive indicators of weaning preparedness, as for invasive mechanical ventilation [5].

Some limitations need further exploration. First, these thresholds should be tested in randomized clinical trials and compared with standard of care. Second, predictors should be sequentially measured at different time-points during zero-PEEP, to assess their performance variability during the weaning trial and unassisted breathing $[2,6]$.
In conclusion, the mROX threshold of $8.4 \mathrm{mmHg} / \mathrm{bpm}$ appears a sensitive and robust predictor of weaning success from helmet CPAP in patients with COVID-19.

\section{Acknowledgements}

The Authors wish to thank all the patients and the healthcare personnel involved in the study and during the COVID-19 pandemic.

\section{Authors' contributions}

D.R., S.P. and P.S. conceived the initial idea and developed the study protocol. All authors were responsible for data acquisition and elaboration and participated in the analysis and the interpretation of data. All Authors drafted, 
critically revised, and gave final approval of the final version of the manuscript. P.S. takes full responsibility of the accuracy and the integrity of the results presented.

\section{Funding}

The work was not funded.

\section{Availability of data and materials}

Individual patient data will be available, upon individual and specific request, to researchers whose proposed use of the data has been approved. Data will be made available request to: pierachille.santus@unimi.it. Data will be provided with investigator support, after approval and after signing a data access agreement. The use of individual patient data outside personal consultation will not be permitted.

\section{Declarations}

Ethics approval and consent to participate

The study (ClinicalTrials.gov: NCT04307459) was designed following the amended Declaration of Helsinki (2013), was approved by the local ethical committee (Comitato Etico Area I: 17263/2020) and all patients gave written informed consent.

\section{Consent for publication}

Not applicable.

\section{Competing interests}

The authors declare that they have no competing interests.

Received: 13 March 2021 Accepted: 6 June 2021

Published online: 12 June 2021

\section{References}

1. Aliberti S, Radovanovic D, Billi F, et al. Helmet CPAP treatment in patients with COVID-19 pneumonia: a multicentre cohort study. Eur Respir J. 2020;56(4):2001935. https://doi.org/10.1183/13993003.01935-2020.

2. Radovanovic D, Rizzi M, Pini S, Saad M, Chiumello DA, Santus P. Helmet CPAP to treat acute hypoxemic respiratory failure in patients with COVID19: a management strategy proposal. J Clin Med. 2020;9(4):1191. https:// doi.org/10.3390/jcm9041191.

3. Karim HMR, Esquinas AM. Success or failure of high-flow nasal oxygen therapy: the ROX index is good, but a modified ROX index may be better. Am J Respir Crit Care Med. 2019;200(1):116-7.

4. Raith EP, Udy AA, Bailey M, et al. Prognostic accuracy of the SOFA score, SIRS criteria, and qSOFA score for in-hospital mortality among adults with suspected infection admitted to the intensive care unit. JAMA. 2017;317(3):290-300.

5. Esteban A, Frutos F, Tobin MJ, et al. A comparison of four methods of weaning patients from mechanical ventilation. Spanish lung failure collaborative group. N Engl J Med. 1995;332(6):345-50. https://doi.org/10. 1056/NEJM199502093320601.

6. Tobin MJ. Extubation and the myth of "minimal ventilator settings." Am J Respir Crit Care Med. 2012;185(4):349-50. https://doi.org/10.1164/rccm. 201201-0050ED.

\section{Publisher's Note}

Springer Nature remains neutral with regard to jurisdictional claims in published maps and institutional affiliations.
Ready to submit your research? Choose BMC and benefit from:

- fast, convenient online submission

- thorough peer review by experienced researchers in your field

- rapid publication on acceptance

- support for research data, including large and complex data types

- gold Open Access which fosters wider collaboration and increased citations

- maximum visibility for your research: over 100M website views per year

At BMC, research is always in progress.

Learn more biomedcentral.com/submissions 